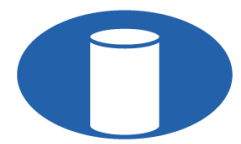

IBRACON Structures and Materials Journal

Revista IBRACON de Estruturas e Materiais

ORIGINAL ARTICLE

\title{
Reinforced concrete beams coated with fiberglass-reinforced polymeric profiles as partial substitutes for the transverse reinforcement
}

\author{
Vigas de concreto armado revestidas com perfis de polímeros reforçados com \\ fibras de vidro como substituto parcial das armaduras transversais
}

\author{
Igor Souza Hoffman ${ }^{\mathrm{a}}$ (D) \\ Jorge Henrique Piva ${ }^{\mathrm{b}}$ \\ Augusto Wanderlind ${ }^{\mathrm{b}}$ (D) \\ Elaine Guglielmi Pavei Antunes ${ }^{\mathrm{b}}$
}

${ }^{a}$ Universidade Federal do Rio Grande do Sul - UFRGS, Programa de Pós-graduação em Engenharia Civil - PPGEC, Porto Alegre, RS, Brasil

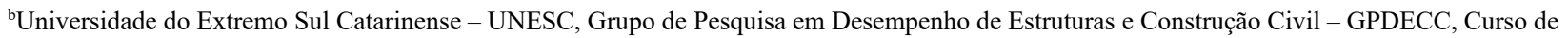
Eng. Civil, Criciúma SC, Brasil

Received 02 November 2019 Accepted 27 Março 2020

\begin{abstract}
The use of GFRP (Glass Fiber Reinforced Polymers) structural profiles in the construction sector is growing due to their attractive properties, such as high mechanical strength and durability in aggressive environments. With this, it is necessary to conduct studies that deepen the knowledge about the performance of these materials in structural applications. Therefore, this work aims to analyze the mechanical performance of reinforced concrete beams coated with GFRP profiles, in comparison to reinforced concrete beams, by analyzing groups with different spacing between transversal reinforcement. In all groups there was no change in the longitudinal reinforcement, and the $\mathrm{D}$ and $\mathrm{Q}$ groups were, respectively, made up of transverse reinforcement spaced twice and quadruple the one calculated for the reference beams, and presented the GFRP profiles in their constitution. All beams were tested at four-point bending, and strain gauges were installed in one of the beams of each group studied. The results obtained in the tests showed an increase in strength of $83.67 \%$ in the beams of group $\mathrm{D}$, and $79.91 \%$ for group $\mathrm{Q}$, in relation to the references. The analysis of longitudinal deformations made it possible to verify increases in stiffness and the moment of cracking in composite beams. Thus, based on this study, the composite structures studied may constitute future solutions for constructions exposed to aggressive environmental conditions, in order to increase their durability and also to contribute to the design of such structural elements with lower reinforcement rates.
\end{abstract}

Keywords: GFRP profile, composite beams, transverse reinforcement, pultrusion.

Resumo: A utilização de perfis estruturais de GFRP (Glass Fiber Reinforced Polymers) no setor da construção civil vem crescendo devido as suas propriedades atrativas, como altas resistências mecânicas e a durabilidade em ambientes agressivos. Com isso, faz-se necessário a realização de estudos que aprofundem o conhecimento sobre o desempenho desses materiais em aplicações estruturais. Sendo assim o presente trabalho tem por objetivo analisar o desempenho mecânico de vigas de concreto armado revestidas com perfis de GFRP, em comparação a vigas de concreto armado, através da análise de grupos com distintos espaçamentos entre armaduras transversais. Em todos os grupos não houve alteração nas armaduras longitudinais, e os grupos D e Q eram constituídos, respectivamente, por armaduras transversais espaçadas conforme o dobro e o quadruplo do calculado para as vigas referência, e apresentavam os perfis de GFRP em sua constituição. Todas as vigas foram ensaiadas a flexão quatro pontos, e strain gauges foram instalados em uma das vigas de cada grupo estudado. Os resultados obtidos nos ensaios apresentaram um aumento de resistência de $83.67 \%$ nas vigas do grupo $\mathrm{D}$, e de $79.91 \%$ para o grupo Q, em relação as referências. A análise de deformações longitudinais possibilitou verificar aumentos de rigidez e o momento de fissuração nas vigas mistas. Sendo assim, com base nesse estudo, as estruturas mistas estudadas podem constituir futuras soluções para construções expostas a

Corresponding author: Elaine Guglielmi Pavei Antunes. E-mail: elainegpa@unesc.net / eelainegpa@gmail.com

Financial support: None.

Co'nflict of interest: Nothing to declare.

This is an Open Access article distributed under the terms of the Creative Commons Attribution License, which permits unrestricted use, distribution, and reproduction in any medium, provided the original work is properly cited. 
condições ambientais agressivas, com o intuito de aumentar a sua durabilidade e, também, contribuir para o dimensionamento de tais elementos estruturais com menores taxas de armadura.

Palavras-chave: Perfil de GFRP, vigas mistas, armaduras transversais, pultrusão.

How to cite: I. S. Hoffman, J. H. Piva, A. Wanderlind, and E. G. P. Antunes, "Reinforced concrete beams coated with fiberglass-reinforced polymeric profiles as partial substitutes for the transverse reinforcement," Rev. IBRACON Estrut. Mater., vol. 13, no. 6, e13608, 2020, https://doi.org/10.1590/S1983-41952020000600008

\section{INTRODUCTION}

The composite materials are defined as a compound substance of two or more materials, combined on a macroscopic scale, insoluble among themselves, to form a useful engineering material with certain properties that are not found in its constituents when in isolation [1], [2]. The use of composites, especially materials formed by fiber-reinforced polymers (FRP- Fiber Reinforced Polymer), has been wide and competitive in some engineering areas [3].

The attractive properties of fiber-reinforced polymers are: durability, corrosion resistance to marine environments; mechanical strength, particularly at low temperatures; ability to resist vibrations and absorb energy under seismic loads; electromagnetic transparency; low coefficient of thermal expansion; pigmentation and decorative characteristics; in addition to an excellent stiffness by weight and strength by weight, therefore, reducing transportation and assembly costs [4], [5]. Due to such properties, its use has been widely studied as a viable substitute for steel of the reinforcement of concrete structures, especially in structures exposed to aggressive environments, which require constant maintenance due to corrosion problems [3], [6], [7]. Although the characteristics and properties of GFRP are also affected in the long term, mainly by the diffusion of humidity through the resin layer and between the fiber and matrix interfaces [8], GFRP, facing more severe exposure conditions, still exhibits greater durability when compared to steel [9], [10]. The GFRP can be commonly seen in civil construction, either in structures made entirely of structural profiles [6] or as a substitute for steel bars in reinforced concrete structures [11] or even in hybrid structures formed by reinforced concrete and GFRP profiles. Hybrid structures formed by bonding GFRP profiles to reinforced concrete elements have been proven to provide a virtually efficient interaction in the short term [12].

The association of GFRP profiles by bonding, through adhesives, in reinforced concrete structural elements, brings economic and mechanical advantages [12], [13]. The GFRP profiles have a low elasticity module [7], therefore, they can demonstrate instability phenomena due to their deformation and, to overcome such limitations, the combined use of GFRP profiles with reinforced concrete, originates a structural solution [3], [13], [14]. Applications of reinforced polymer profiles with externally connected fiberglass play a fundamental role in guaranteeing the strength and stiffness of buildings, mainly due to the bold designs of modern buildings [13].

In addition to the strength requirements, GFRP also serves as a protective shield for structural elements against adverse environmental and meteorological conditions, such as, for example, the penetration of carbon chloride ions [15]. In view of these notes, the present work aims to analyze the mechanical performance of composite reinforced concrete beams with GFRP profiles, in comparison to reinforced concrete beams commonly used in civil construction, through the analysis of groups with different spacing between transverse reinforcement. Therefore, the samples of each group are submitted to bending moment and shear forces, to study the behavior of the composite structure, and to analyze the performance of the profiles used as partial substitutes for the transverse reinforcement.

\section{MATERIALS AND METHODS}

\subsection{Methodology}

In order to fulfill the objectives of this study, three different groups of beams were performed, group REF, D and Q, consisting of three samples each. For all groups, the structural elements had a total length of $160 \mathrm{~cm}$, and an effective span of $150 \mathrm{~cm}$, as can be seen in Figure 1.

The GFRP profiles constitute a collaborative structural form, which serves as a formwork for the execution of the beams and as a structural element. The longitudinal reinforcements were kept constant in all groups, being composed of a pair of $12.5 \mathrm{~mm}$ diameter ribbed CA-50 steel bars, totaling a steel area of $2.50 \mathrm{~cm}^{2}$.

The verification of the rupture mode for the reference beams was carried out by determining the depth of the neutral line (NL) for the ultimate limit state (ULS), according to the recommendations of NBR 6118 [16], considering the balance of the tension forces in the reinforcement and compression in concrete according to the stress distributions for Stadium 3 deformations. With the determination of the depth of the neutral line, it is possible to evaluate the deformation 
domain that will characterize the rupture mode of these structural elements, by considering the Bernoulli hypothesis for flat sections. The final theoretical strength moment for the reinforced concrete reference beams can be determined through Equation 1.

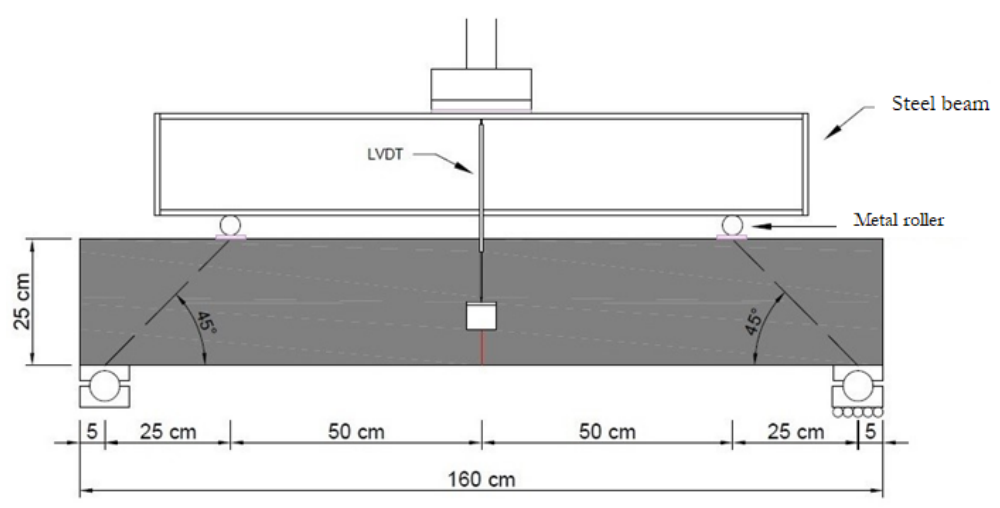

Figure 1. Schematic of the four-point bending test carried out on the beams.

$M_{u}=\left(f_{y k} / \gamma_{s}\right) \cdot A_{s} \cdot(d-0,4 x)$

Where:

$M_{u}$ - last resistant moment for the beam in the ULS; $A_{s}$ - total steel area of the main longitudinal reinforcements; $d$ - useful beam height; $x$ - depth of the neutral line; $f_{y k}$ - characteristic steel yield strength; $\gamma_{s}$ - coefficient for the reduction of steel strength. In this work $\gamma_{\mathrm{s}}=1.0$.

The calculation of the predicted moment for the beginning of the cracking in the reference beams due to the tensile efforts in the concrete was carried out according two methodologies: Approximate method, according to NBR 6118 [16], and the homogenized sections method. According to NBR 6118 [16], the moment of cracking in reinforced concrete beams is given by Equation 2 .

$M_{r}=\frac{\alpha \cdot f_{c t k, i n f} \cdot I_{c}}{y_{t}}$

Where:

$M_{r}$ - expected cracking moment of the structural element; $\alpha=1.5$ for rectangular cross sections; $I_{c}-$ moment of inertia of the concrete section; $f_{c t, i n f}$ - lower tensile strength of concrete given by $f_{c t, i n f}=0.21 \cdot f_{c k}^{2 / 3} ; y_{t}$ - distance from the center of gravity to the most strained fiber.

The homogenized section methodology considered the transformation of the reinforced concrete cross section into an equivalent theoretical section of concrete. The beginning of cracking in the tensioned concrete is characterized by the passage from Stadium 1 to Stadium 2 of deformations. Therefore, when the stresses acting on the stretched concrete fibers reach the lower tensile strength $\left(f_{c t, i n f}\right)$, the cracking process begins. The position of the neutral line in Stadium I of deformations is given by Equation 3.

$x_{h}=\frac{-B}{A}$

Where:

$x_{h}$ - position on the neutral line in Stadium I of deformations considering the homogenized section, measured from the upper end of the beam; Coefficients A and B in Equation 3 are given by Equations 4 and 5. 
$A=b_{w} \cdot h+A_{s} \cdot(\eta-1)$

$B=\frac{-b_{W}}{2} \cdot h^{2}-A_{s} \cdot d \cdot(\eta-1)$

Where:

$b_{w}$ - width of the cross section; $h$ - total beam height; $A_{s}$ - total steel area of the main longitudinal reinforcements; $d$ - useful beam height; The homogenization coefficient of sections $\eta$ is given by Equation 6 .

$\eta=\frac{E_{s}}{E_{c s}}$

Where:

$E_{s}$ - modulus of elasticity of steel. For this work $E_{s}=210 \mathrm{MPa} ; E_{c s}$ - secant elasticity modulus predicted for concrete. $E_{c s}=\alpha_{i} \cdot E_{c i} ;$ the value of $\alpha_{i}=0.90$ for $\mathrm{f}_{\mathrm{ck}}=40 \mathrm{MPa}$, and $E_{c i}=\alpha_{E} \cdot 5600 \cdot \sqrt{f_{c k}} ; \alpha_{E}=1.20$.

The theoretical cracking moment for the homogenized concrete section will be given by Equation 7 .

$M_{r h}=\frac{f_{c t k, i n f} \cdot I_{c h}}{y_{t}}$

Where:

$M_{r h}$ - cracking moment in concrete section; $I_{c h}$ - moment of inertia of the section; $f_{c t k, \text { inf }}$ - lower tensile strength of concrete; $y_{t}$ - Position of the most strained fiber in relation to the neutral line, given by $y_{t}=h-x_{h}$.

Through the four-point bending test model considered for this work, presented in Figure 1, it is possible to describe the equation that relates the moment applied at the center of the effective span to the loads measured in the HBM U10M load cell. Once the moments of cracking and collapse are known, obtained theoretically, one can predict the loading observed in the load cell for each of these cases through Equations 8 and 9.

$P=\left(M+\frac{\rho_{c a} \cdot A_{C}}{2} \cdot\left(-\frac{1}{4} \cdot L_{e f}^{2}\right)\right) / l_{a p}$

$P_{C C}=2 \cdot P$

Where:

$P$ - point load applied in the test; $P_{C C}$ - expected loading in the load cell; $M$ - moment observed in the center of the theoretical span of the beams; $\rho_{c a}$ - specific weight considered for reinforced concrete, being $\rho_{c a}=25 \mathrm{kN} / \mathrm{m}^{3} ; A_{C}-$ crosssectional area of the rectangular reinforced concrete beam; $L_{e f}$ - effective span of the beam considered, being $L_{e f}=1.50 \mathrm{~m}$; $l_{a p}$ - distance from the point of application of the test loads, measured from the model supports, being $l_{a p}=0.25 \mathrm{~m}$.

The transverse reinforcement was determined using the methodology of model I and II of calculation, according to NBR 6118 [16], considering for the second model the angle of the compression rod $\Theta=45^{\circ}$ (as indicated in the structure of the tests shown in Figure 1), and the angle of the transverse reinforcement of $\alpha=90^{\circ}$. In addition, the necessary spacing was verified by considering the ultimate limit state for the plastification of the transverse reinforcement, disregarding the calculation parcels referring to the complementary resistance mechanisms, such as the effects of aggregate gearing and the effect of reinforcement pins between cracks. All calculations were performed considering that the transverse reinforcement was composed of simple branches with ribbed CA-50 steel bars of $6.30 \mathrm{~mm}$ in diameter. Equation 10 [17] was used to determine the longitudinal spacing between the reinforcements. 
$s=\frac{A_{s w} \cdot d \cdot\left(f_{y k} / \gamma_{s}\right)}{1.10 \cdot V_{s}}$

Where:

$s$ - longitudinal spacing of transverse reinforcement; $A_{s w}$ - cross sectional area of shear reinforcement; $f_{y k}-$ characteristic yield strength steel, being $f_{y k}=500 \mathrm{MPa} ; \gamma_{s}$ - coefficient for the reduction of steel strength. In this work $\gamma_{s}=1.0 ; V_{s}$ - active shear force.

Table 1 presents the longitudinal spacing calculated for each design methodology considered in this work.

Table 1. Longitudinal spacing of transverse reinforcement, for $6.30 \mathrm{~mm}$ diameter bars.

\begin{tabular}{cc}
\hline Methodology & Longitudinal spacing (s) \\
\hline Model I & $11.43 \mathrm{~cm}$ \\
\hline Model II & $9.58 \mathrm{~cm}$ \\
\hline Calculation using Equation 10 & $6.07 \mathrm{~cm}$ \\
\hline
\end{tabular}

All the beams of the groups (Ref, D and Q) were made with a concrete cross section of $15 \times 25 \mathrm{~cm}$ and in groups D and Q GFRP profiles were used. The longitudinal reinforcement for all groups were two bars of $12.5 \mathrm{~mm}$ diameter (2 $\Phi 12.5 \mathrm{~mm}$ ). Spacing of transverse reinforcement used in groups Ref, Q and D was $7 \mathrm{~cm}, 14 \mathrm{~cm}$ and $28 \mathrm{~cm}$, respectively.

The collaborative form of GFRP, if treated as a structural reinforcement, can add mechanical strength to both shear and bending. The American standard ACI 440 2R-08 Guide for the Design and Construction of Externally Bonded FRP Systems for Strengthening Concrete Structures [18] has recommendations and analytical formulas capable of quantifying these reinforcements. Following the ACI 440 2R-08 standard [18], the shear strength can be calculated with Equation 11.

$\varnothing V_{n}=\varnothing \cdot\left(V_{c}+V_{s}+\varphi_{f} \cdot V_{f}\right)$

Where:

$\varnothing$ - lessening strength factor; $V_{n}$ - nominal shear strength; $V_{c}$ - shear strength related to concrete; $V_{s}$ - shear strength related to steel: $\varphi_{f}$ - coefficient of reduction of reinforcement efficiency; $V_{f}$ - shear strength related to reinforcement.

For the study of this work, the factor $\emptyset$ was adopted as 1.0 , in order to compare with the experimental responses and the coefficient $\varphi_{f}$ was adopted with the value of 0.85 , which is recommended when the reinforcement has a " $U$ " geometry. The strengths $V_{c}$ and $V_{s}$ were calculated with Equations 12 and 13, taken from the American standard ACI 318-05 Building Code Requirements for Structural Concrete and Commentary [19].

$V_{c}=2 \cdot \sqrt{f_{c}^{\prime}} \cdot b_{w} \cdot d$

$V_{s}=\frac{A_{v} \cdot f_{y t} \cdot d}{s}$

Where:

$f^{\prime}{ }_{c}$ - characteristic compressive strength of concrete; $b_{w}$ - width of the cross section of the concrete beam; $\mathrm{d}$ - distance from the most compressed face to the centroid of the longitudinal steel reinforcement; $A_{v}$ - area of steel transverse reinforcement with spacing s;

$f_{y t}$ - yield strength of the transverse reinforcement; $s$ - spacing between transverse reinforcements.

In Equation 12 the unit of psi for $f^{\prime}{ }_{c}$ should be used. The other equations in the article are adapted to use the units of the international system. The equation for obtaining the strength $V_{f}$ contained in that standard is based on spaced 
reinforcements. However, the collaborative form characterizes a continuous reinforcement, thus the shear strength offered by it was computed assuming that the two webs of the GFRP profile act integrally. Equations 14 and 15 are used for its calculation.

$V_{f}=A_{f v} \cdot f_{f e}$

$A_{f v}=2 \cdot t_{f} \cdot d_{f v}$

Where:

$A_{f v}$ - shear reinforcement area from GFRP; $f_{f e}$ - effective tensile strength of GFRP; $t_{f}$ - web thickness of the collaborative form GFRP; $d_{f v}$ - web height of the collaborative form of GFRP.

In order to obtain $f_{f e}$ acting against the shear, the linear relationship by Hooke's law can be used, but an effective deformation $\left(\varepsilon_{f e}\right)$ must be considered, which experimentally obtains values lower than those of the concrete fracture, characterizing a fracture by disconnection of the reinforcement with concrete [20]. Equations 16, 17, 18, 19, 20 and 24 lead to characterize the behavior of the shear reinforcement until obtaining $\varepsilon_{f e}$, which is a function of the strength of the concrete, the cross section of the reinforcement and the stiffness of the reinforcement [21].

$\varepsilon_{f e}=k_{v} \cdot \varepsilon_{f u}$

$k_{v}=\frac{k_{1} \cdot k_{2} \cdot L_{e}}{11900 \cdot \varepsilon_{f u}}$

$k_{1}=\left(\frac{f_{c}^{\prime}}{27}\right)^{2 / 3}$

$k_{2}=\frac{d_{f v}-L_{e}}{d_{f v}}$

$L_{e}=\frac{23300}{\left(n_{f} \cdot t_{f} \cdot E_{f}\right)^{0.58}}$

Where:

$k_{v}$ - reduction coefficient of the shear deformation efficiency; $\varepsilon_{f u}$ - limit deformation for rupture of the GFRP; $k_{1}$ reduction factor due to the influence of concrete strength; $k_{2}$ - reduction factor due to the influence of the "U" type transverse section of the reinforcement; $n_{f}$ - number of reinforcement layers; $E_{f}$ - longitudinal elastic modulus of the GFRP; $L_{e}$ - active length of the connection of the GFRP with the concrete over which most of the shear tension is maintained.

According to the ACI 440 2R-08 [18] standard, the flexural strength of the reinforced beam can be calculated with the collaborating formwork. Considering only the plate on the underside of the U profile as an active reinforcement, Equation 21 was used for the calculation.

$M_{n}=A_{s} \cdot f_{s} \cdot\left(d-\frac{\beta_{I} \cdot c}{2}\right)+\varphi_{f} \cdot A_{f} \cdot f_{f e} \cdot\left(h-\frac{\beta_{I} \cdot c}{2}\right)$ 
Where:

$M_{n}$ - nominal moment strength considering the bending reinforcement; $A_{s}$ - steel area of longitudinal reinforcement; $f_{s}$ - stress resisted by steel bars; $A_{f}$ - bottom plate area of GFRP; $h$ - total beam height; $\beta_{l}$ - ratio between the depth of the equivalent rectangular stress block and the depth of the neutral axis taken as the values associated with the Whitney stress block; $c$ - distance from the most compressed face to the neutral axis.

The other terms of Equation 21 have been previously described, with the $\varphi_{f}$ coefficient also being adopted as 0.85 .

The term $c$ must be calculated iteratively, to produce the compatibility of the deformations in the materials and the equivalence of the internal forces. For this, the deformations are calculated with Equations 22 and 23 arbitrating the value of $c$. Equations 24 and 25 are used to obtain the stresses. After obtaining the deformations and stresses, Equation 26 is used to carry out the internal balance of forces and thus verify that the dimension $c$ adopted satisfies the conditions of compatibility and balance.

$\varepsilon_{f e}=\varepsilon_{c u}\left(\frac{d_{f}-c}{c}\right) \leq \varepsilon_{f d}$

$\varepsilon_{s}=\varepsilon_{f e} \cdot\left(\frac{d-c}{d_{f}-c}\right)$

$f_{f e}=E_{f} \cdot \varepsilon_{f e}$

$f_{s}=E_{s} \cdot \varepsilon_{s} \leq f_{y}$

$c=\frac{A_{s} \cdot f_{s}+A_{f} \cdot f_{f e}}{\alpha_{1} \cdot f^{\prime} \cdot \beta_{l} \cdot \beta_{w}}$

Where:

$\varepsilon_{f e}$ - effective deformation of the GFRP; $\varepsilon_{c u}$ - ultimate deformation of the concrete obtained by the stress-strain graph at the point equal to $0.85 \cdot f_{c}$ or equal to $0.003 ; \varepsilon_{f d}$ - limit deformation to disconnect the GFRP from the concrete; $\varepsilon_{s}$ deformation of steel; $E_{s}$ - modulus of elasticity of steel; $f_{y}$ - yield stress of steel; $\alpha_{1}$ - multiplication factor to determine the stress intensity in the concrete using the rectangular distribution.

The other terms can be seen in Figure 2a, which shows the transverse section adopted for the flexural reinforcement model. Figures $2 \mathrm{~b}$ and $2 \mathrm{c}$ present, respectively, the diagram of the distribution of deformations and the diagram of the balance of internal forces.

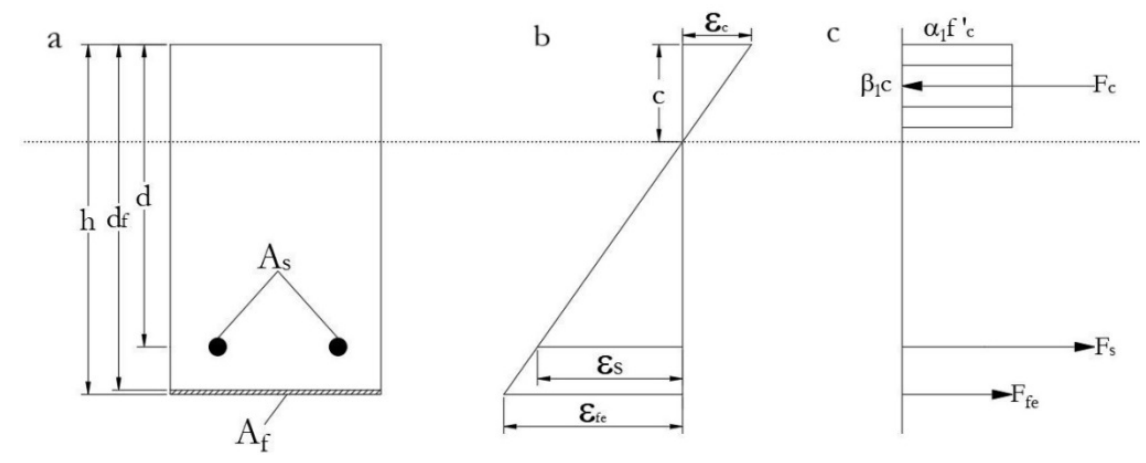

Figure 2. a) Cross section for the model adopted of bending with action of the collaborating form. b) Diagram of deformations of the beam c) Diagram of balance of internal forces acting on the beam in bending. 
However, if Equation 22 presents $\varepsilon_{f e}$ greater than $\varepsilon_{f d}$, the concrete does not reach $\varepsilon_{c u}$ thus the failure is characterized by the disconnection of the GFRP with the concrete [22]. In the work (Teng et al [23]) an equation was developed based on experimental data and fracture mechanics. This equation was adapted by the ACI 440 2R-08 [18] standard from a committee that evaluated a significant number of experimental data on beams subjected to bending, which suffered failure due to disconnection of the reinforcement. Equation 27 is then used to calculate $\varepsilon_{f d}$ based on the equation proposed by (Teng et al [23]), calibrated by the coefficient equal to 0.41 proposed by the standard.

$$
\varepsilon_{f d}=0.41 \cdot \sqrt{\frac{f_{c}^{\prime}}{n_{f} \cdot E_{f} \cdot t_{f}}}
$$

In this case, the deformation in the concrete will be less than its ultimate deformation and will need to be calculated, which can be obtained by similarity of triangles, as provided by Equation 28 .

$$
\varepsilon_{c}=\varepsilon_{f e}\left(\frac{c}{d_{f}-c}\right)
$$

After the concreting activities, shown in Figure 3, the beams were covered with tarpaulins, in order to avoid water losses in the concrete mixture, and the specimens were placed in a tank with water and calcium hydroxide solution, according to the specification of NBR 5738 [24].

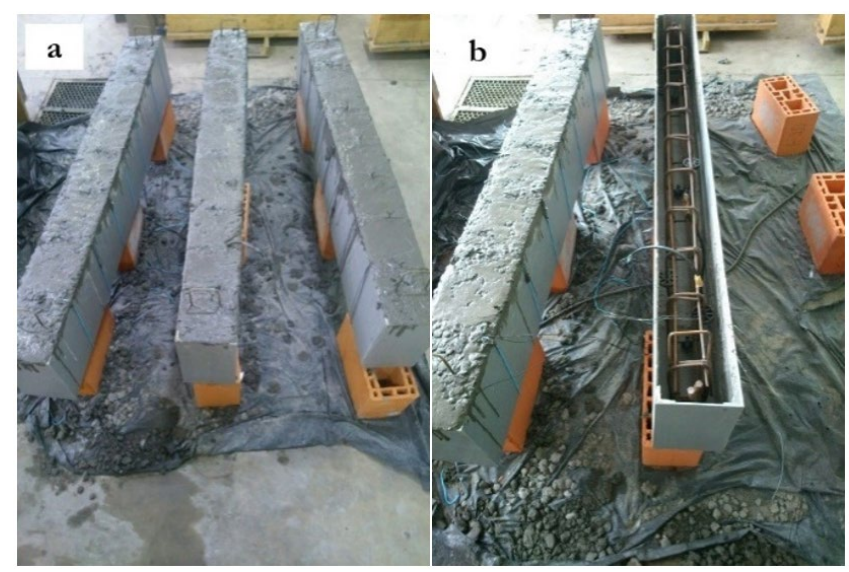

Figure 3. a) Composite concrete beams in GFRP profiles. b) Concreting of composite concrete beams in GFRP profiles.

The tests were carried out 28 days after the concreting of the elements, thus respecting the curing time. All beams were subjected to four-point bending tests, following the model of ASTM C78 / C78M [25] with adaptations in relation to the height of the beams, definitions of supports and load application positions, as these were positioned close to the supports, forming an angle of $45^{\circ}$ in relation to the support, in order to increase the shear forces in the tested beams. The tests were carried out with the use of a hydraulic piston with a maximum capacity of $500 \mathrm{kN}$, supported under a reaction frame. To obtain the values of vertical deflections, a LVDT of $100 \mathrm{~mm}$ was used. The four-point bending test scheme, as well as the orientations of the load application positions and LVDT positioning already presented in Figure 1.

The strain gauges were inserted in the upper concrete face in beams "REF-1", "D-1" and "Q-1", Figure 4a, and in the lower part in beams "D-1 "and" Q-1 ", in GFRP forms, Figure 4b. In addition to these, a strain gauge was inserted in one of the bars that make up the lower longitudinal reinforcement in beams "REF-1", "D-1" and "Q-1", Figure 4c. 


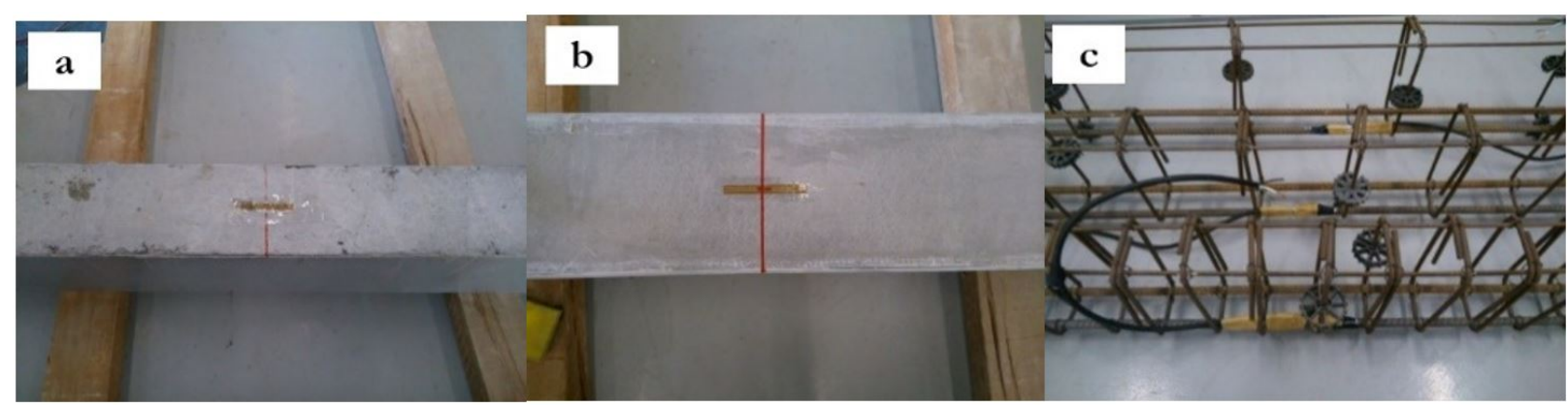

Figure 4. a) Strain gauge in concrete. b) Strain gauge in GFRP profile. c) Strain gages in REF, D and Q group reinforcement.

All sensors were positioned at the center of the theoretical span. The sensors used in the tests were connected to a Quantum X MX840 data acquisition module of the HBM brand, and the software used for receiving, recording and synchronizing data was Catman 3.0.

The axial compression tests were performed according to NBR 5739 [26], on a hydraulic press model EMIC PC200I, with a maximum capacity of $2000 \mathrm{kN}$. The elasticity modules were obtained through tests carried out according to NBR 8522 [27], in a hydraulic press model EMIC PC200CS, with a maximum capacity of $2000 \mathrm{kN}$.

\subsection{Materials}

The GFRP profiles were consisted of an electro-gutter profile with the dimensions of $15.00 \times 10.00 \times 0.32 \mathrm{~cm}$ (width $\mathrm{x}$ height $\mathrm{x}$ thickness), and two plates of $25.00 \mathrm{x} 0.32 \mathrm{~cm}$ (width $\mathrm{x}$ thickness), which were glued on both sides of the walls of the electro-gutter profile using polyurethane glue. Then, a transverse section was obtained with the final dimensions of $15.00 \times 25.00 \mathrm{~cm}$ (width $\times$ height), $0.32 \mathrm{~cm}$ thick and a total length of $160 \mathrm{~cm}$, maintained in all forms used, as shown in Figure 5.

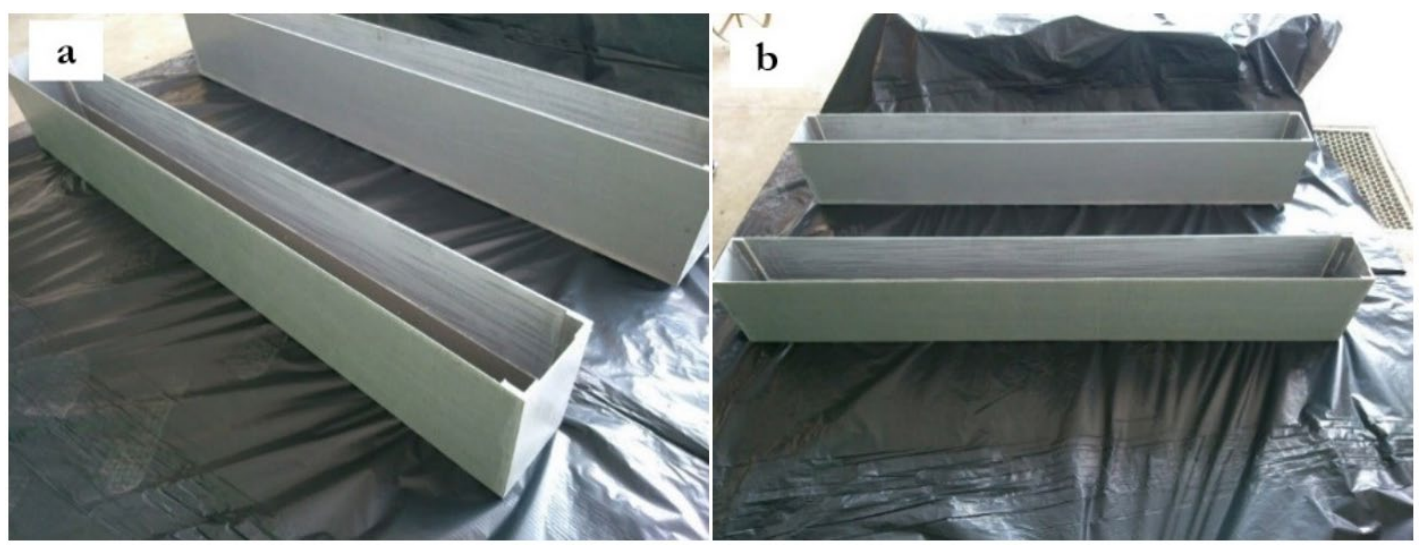

Figure 5. GFRP profiles used in groups D and Q.

The profiles are pultruded and have a minimum fiber/resin ratio of $55 \%$. The mechanical properties of interest for using the collaborative form as reinforcement, longitudinal modulus of elasticity $\left(E_{f}\right)$, the tensile strength $\left(f_{f u}\right)$ and the deformation at rupture $\left(\varepsilon_{f u}\right)$, were measured by uniaxial tensile testing performed on a universal testing machine of EMIC brand, model DL30000 with the aid of a clip-gauge, with the following results respectively; $21358 \pm 524.74 \mathrm{MPa}, 265.2 \pm 1.48 \mathrm{MPa}$ and $0.011717 \pm 0.000957 \mathrm{~mm} / \mathrm{mm}$.

Stress-strain behavior presented by the specimens can be seen in the graph of Figure 6, these were linear until their rupture, which was fragile. The GFRP profiles generally have a specific mass of $1800 \mathrm{~kg} / \mathrm{m}^{3}$, as indicated by the material supplier company. 


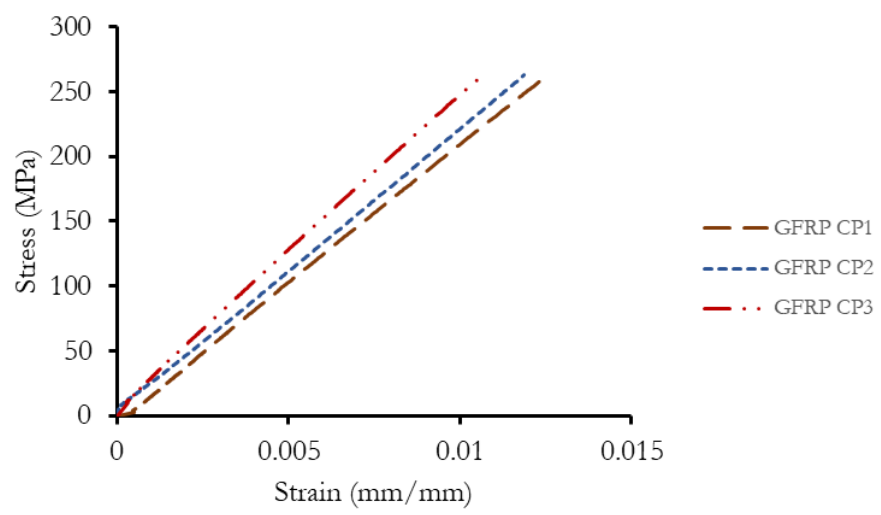

Figure 6. Stress versus strain graph obtained by the uniaxial tensile test on 3 GFRP specimens.

The yield stress $\left(f_{y}\right)$ and the tensile strength limit stress $\left(f_{u}\right)$ for the CA-50 steel used were determined by uniaxial tensile testing performed on the same universal testing machine. In this test it was not possible to use an extensometer, a fact that made the correct measurement of the longitudinal elastic modulus $\left(E_{s}\right)$ impossible, which was adopted equal to $210 \mathrm{GPa}$, a value recommended by NBR 6118: 2014 [16].

The concrete used in the beams was dosed to present a compressive strength of $40 \mathrm{MPa}$ after 28 days. The cement used was of the CPIV-32 type with property resistant to aggressive environments, mainly to the attack of sulfides. The unitary mix was executed in mass in the following proportion, $1: 2.87: 2.13$ with water/cement ratio of 0.48 and addition of polypropylene fiber equal to $0.90 \mathrm{~kg} / \mathrm{m}^{3}$ of concrete. The reduction of the cone trunk on the slump test, according to NBR NM 67 [28] was $70 \pm 20 \mathrm{~mm}$. The aggregates used in the concrete were characterized according to NBR NM 248 [29]. The concrete was reinforced with the use of multifilament polypropylene fibers, in order to reduce the risk of plastic cracking (effect of shrinkage in the concrete) [30], thus improving the performance of the profile/concrete adhesion, which was accomplished through the use of an epoxy resin.

The fiber content used was $0.9 \mathrm{~kg} / \mathrm{m}^{3}$, since low fiber contents between 0.9 to $2.7 \mathrm{~kg} / \mathrm{m}^{3}$ do not influence the increase in concrete strength [31].

The connection between the GFRP profile and the concrete was carried out with the use of a bicomponent thixotropic epoxy resin. The application was carried out on the walls of the profile, in the areas close to the supports of the beams (region of greater shear force) and in the area of the bottom of the profiles, which comprise the places that present the greatest bending moments. The regions where the resin was applied are shown in the areas indicated in Figure 7.

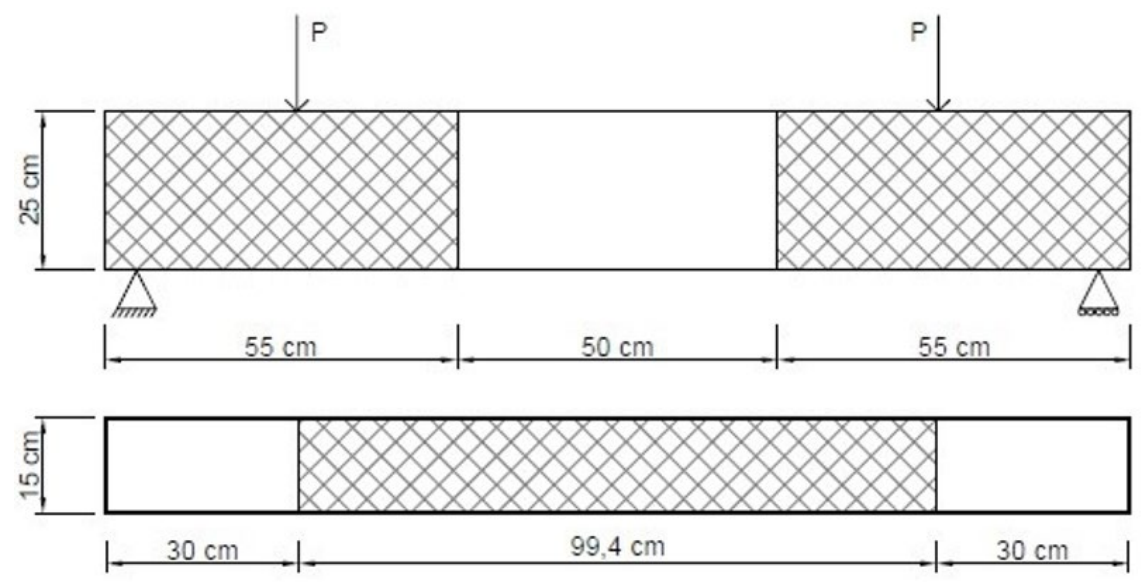

Figure 7. Regions of application of resin on the walls and bottom of the moulds, respectively. 
The application of the resin was carried out manually, using spatulas, with a thickness of approximately $2 \mathrm{~mm}$ of glue, as indicated manufacturer.

\section{RESULTS AND DISCUSSIONS}

\subsection{Efforts and acting requests on the beams theoretically obtained}

Table 2 presents the results of the theoretical efforts calculated according to the equations presented in section 2 of this work. The results obtained are regarding the reinforced concrete beams.

Table 2. Results of the theoretical efforts calculated according to the equations presented in section 2

\begin{tabular}{|c|c|}
\hline Useful beam height - d & $21.875 \mathrm{~cm}$ \\
\hline Depth of the neutral line in the ULS - $x$ & $2.56 \mathrm{~cm}$ \\
\hline $\mathrm{x} / \mathrm{d}$ ratio & 0.12 \\
\hline Domains of deformations in the ULS & 2 \\
\hline Deformations of reinforcements in the ULS & $10 \%$ \\
\hline Deformations of concrete in the ULS & $1.32 \%$ \\
\hline Last resistant moment $-M_{u}$ & $25.59 \mathrm{kN} \cdot \mathrm{m}$ \\
\hline Load measured in the load cell in the ULS - $P_{C C u}$ & $202.61 \mathrm{kN}$ \\
\hline Cracking moment predicted by NBR $6118-M_{r}$ & $5.76 \mathrm{kN} \cdot \mathrm{m}$ \\
\hline Load measured in the load cell for cracking $-P_{C C r}$ & $43.94 \mathrm{kN}$ \\
\hline Cracking moment predicted through the homogenized concrete section- $M_{r h}$ & $4.11 \mathrm{kN} \cdot \mathrm{m}$ \\
\hline Load measured in the load cell for cracking $-P_{C C r h}$ & $30.78 \mathrm{kN}$ \\
\hline
\end{tabular}

Through the methodologies for checking the deformation domains for the ultimate limit state, according to NBR 6118 [16], it was found that the rupture of the reinforced concrete beams meets the ductility recommendations, with no fragile rupture in the bending elements. The rupture mechanism foreseen for the tested reinforced concrete beams will be the flow of the drawn longitudinal reinforcements, and the deformations in the most compressed concrete fibers do not reach the deformation limit for the beginning of plasticization, given as $\varepsilon_{c 2}=2.00 \%$ by NBR 6118 [16], for concretes com $f_{c k} \leq 50 \mathrm{MPa}$. The theoretical shear strength $\left(V_{n}\right)$ for beam group $\mathrm{D}$ is $185 \mathrm{kN}$ and for beam group Q $158 \mathrm{kN}$, while the theoretical $M_{n}$ for reinforced beams was $45.6 \mathrm{kN} \cdot \mathrm{m}$.

\subsection{Axial compression and modulus of elasticity of concrete}

The average axial compression strength and elasticity modulus results obtained for the respective groups Ref, D and Q were, $45.27 \pm 1.88 \mathrm{MPa} ; 41.80 \pm 2.29 \mathrm{MPa} ; 43.55 \pm 1.33 \mathrm{MPa}$ and elasticity modulus $44.70 \pm$ $2.08 \mathrm{GPa} ; 44.38 \pm 2.05 \mathrm{GPa} ; 45.58 \pm 1.81 \mathrm{GPa}$.

Through the results obtained, the concrete used for molding the beams presented axial compression strength close to the pre-established for this work.

\subsection{Analysis of loads and vertical displacements of beams}

During the tests, limits were set in relation to the load applied by the hydraulic piston on the beams, in order to avoid damage to the equipment used, for that purpose the application of up to $450 \mathrm{kN}$ was kept as a limit. Figure 8 presents the graph with the results of the loads and vertical displacements obtained for the reference beams (REF), beams of group D and Q.

The average maximum load for the beams of group D was $439.03 \mathrm{kN}$, an increase of $83.67 \%$ in relation to the structural elements of the REF group, which had an average maximum load of rupture of $239.03 \mathrm{kN}$. For the beams of group Q, the average maximum load was $430.04 \mathrm{kN}$, an increase of $79.91 \%$ in relation to the elements of the REF group, and a difference of $2.05 \%$ in relation to the average maximum load of group D beams.

Table 3 presents the mechanical results for each tested beam, as well as the load obtained for the maximum vertical service displacement, which according to NBR 6118 [16] is L/250, with L being the effective span of the beam 
considered. To calculate the maximum shear forces and maximum bending moments, the specific weight of reinforced concrete was used as $\rho=25 \mathrm{kN} / \mathrm{m}^{3}$.

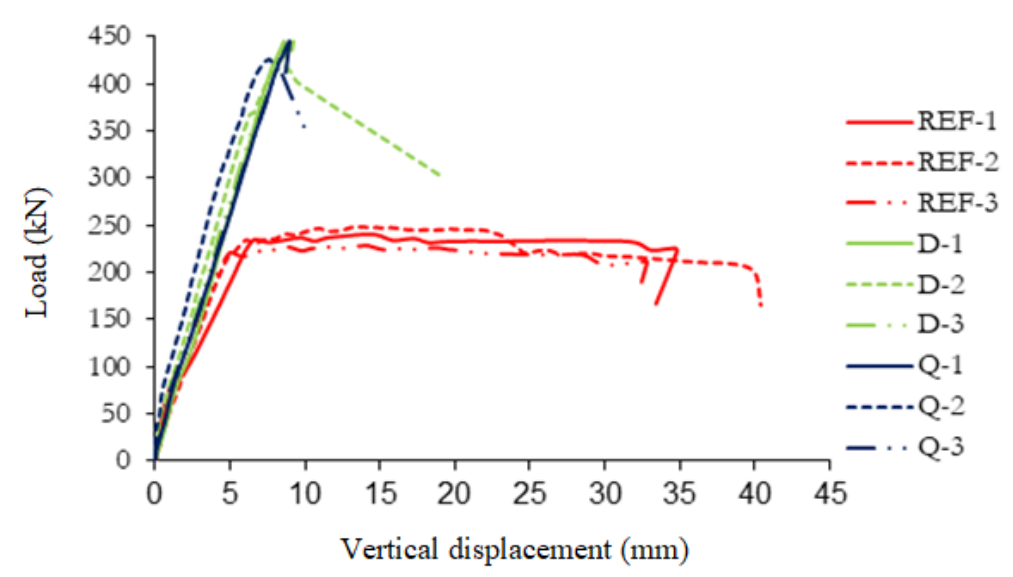

Figure 8. Graph of loads and vertical displacements for each tested beam.

Table 3. Mechanical results for each tested beam

\begin{tabular}{|c|c|c|c|c|c|c|}
\hline Group & Beams & $\begin{array}{c}\mathrm{L} / 250=6 \mathrm{~mm} \\
\mathrm{Load} \text { in } \mathrm{L} / 250 \\
(\mathrm{kN})\end{array}$ & $\begin{array}{c}\text { Maximum load } \\
(\mathbf{k N})\end{array}$ & $\begin{array}{l}\text { Displacement vertical } \\
\text { in maximum load } \\
(\mathrm{mm})\end{array}$ & $\begin{array}{l}\text { Maximum shear } \\
\text { force }(k N)\end{array}$ & $\begin{array}{c}\text { Maximum } \\
\text { bending moment } \\
(\mathrm{kN} \cdot \mathrm{m})\end{array}$ \\
\hline \multirow{5}{*}{ REF } & REF-1 & 223.31 & 240.61 & 14.27 & 121.01 & 30.34 \\
\hline & REF-2 & 234.30 & 248.31 & 13.50 & 124.86 & 31.30 \\
\hline & REF-3 & 216.92 & 228.17 & 14.02 & 114.79 & 28.78 \\
\hline & Average & 224.84 & 239.03 & 13.93 & 120.22 & 30.14 \\
\hline & S.D. & 8.79 & 10.16 & 0.39 & 5.08 & 1.27 \\
\hline \multirow{5}{*}{$\mathrm{D}$} & D-1 & 320.25 & 445.50 & 8.58 & 223.46 & 55.95 \\
\hline & D-2 & 356.55 & 426.05 & 8.31 & 213.73 & 53.52 \\
\hline & D-3 & 330.83 & 445.54 & 9.23 & 223.48 & 55.96 \\
\hline & Average & 335.88 & 439.03 & 8.71 & 220.22 & 55.14 \\
\hline & S.D. & 18.67 & 11.24 & 0.47 & 5.62 & 1.41 \\
\hline \multirow{5}{*}{ Q } & Q-1 & 315.14 & 446.20 & 8.90 & 223.81 & 56.04 \\
\hline & Q-2 & 381.69 & 425.09 & 7.57 & 213.25 & 53.40 \\
\hline & Q-3 & 315.27 & 418.83 & 8.25 & 210.12 & 52.62 \\
\hline & Average & 337.37 & 430.04 & 8.24 & 215.73 & 54.02 \\
\hline & S.D. & 38.39 & 14.34 & 0.67 & 7.17 & 1.79 \\
\hline
\end{tabular}

The vertical displacements observed experimentally during the tests of the beams, were obtained at the moment of the maximum applied load. For the elements of group D, the average vertical displacement was $8.71 \mathrm{~mm}$, which is $37.50 \%$ less than the average vertical displacement obtained for beams in the REF group, which was $13.93 \mathrm{~mm}$. Among the samples in group Q, the average vertical displacement was $8.24 \mathrm{~mm}$, a difference of $40.85 \%$ in relation to the beams in the REF group, and a difference of $5.36 \%$ in relation to the elements in group D.

It can be seen through the graph in Figure 8 that the vertical displacements obtained of the REF group are contained in the Stadium III deformations, when the beams were in state collapse. And the values found for the samples of group D and Q were obtained while the elements were in the Stadium II of deformations, before the collapse of the structures.

\subsection{Analysis of loads and longitudinal deformations in the materials}

Figure 9 presents the results of deformations of the materials during the four-point bending tests, in relation to the resulting bending moment in the center of the theoretical span. 

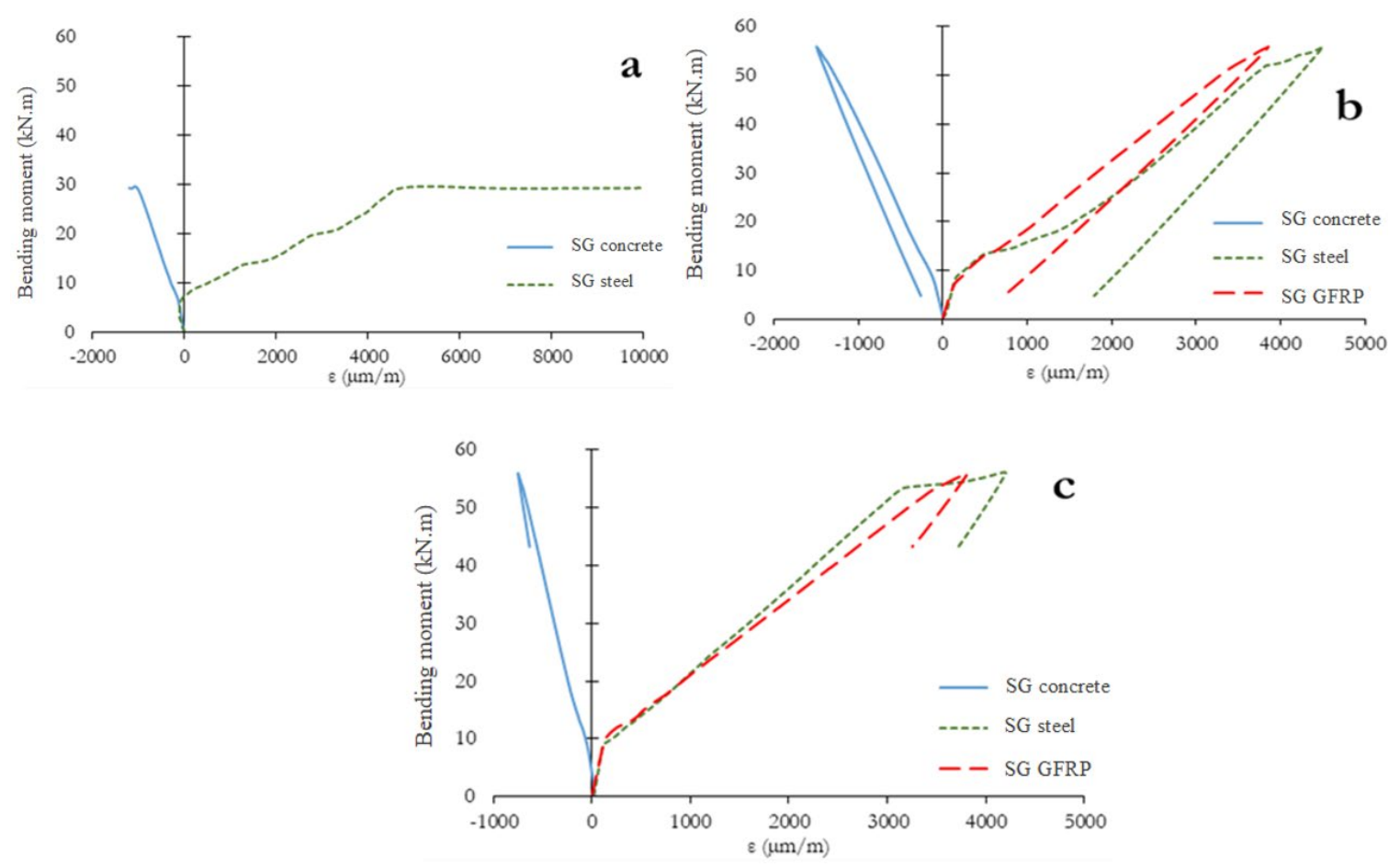

Figure 9. Graph of bending moment and longitudinal strain of the materials for the beams a) REF-1; b) D-1; c) Q-1.

The curves shown in Figure 9 demonstrate through the values of longitudinal deformations, that the steel and the GFRP profiles were, together, responsible for the resistance to the tensile stresses in the structural elements tested in groups D and Q. note that the beams of the reference group presented, in their collapsed state, plastification deformations in the tensioned reinforcements, while the concrete remained in linear-elastic behavior, thus corroborating the theoretical model predicted for the deformation domain 2, according to NBR 6118 [16].

It is also possible to observe the elastic-linear behavior of the GFRP profiles throughout the test, as well as for the concrete in the compressed region, which in all samples did not present a compression rupture at the moment of collapse, and the measured deformations did not reach the values foreseen for the beginning of the appearance of plastic deformations.

The results obtained for the longitudinal deformations of the steel bars in the beams REF-1, D-1 and Q-1 show, through the first change in the inclination of the lines in the graphs, the cracking moments in the structural elements, when the beams pass Deformation Stadium I for Stadium II. This increase in deformations in the bars, shown in the graphs by the sudden increases in deformations for a small variation in the bending moments, reflects the increase in stresses in the tensioned bars due to the appearance of cracks in the adhesion regions [32]. At these high points, adhesion stresses arise due to the difference in deformations between steel bars and concrete, which result in loss of adhesion due to adhesion, which in the case of ribbed bars give rise to transversal cracks in these regions.

It is also observed that after the moment of cracking, all the materials that make up the beams demonstrate changes in the inclination of the straight lines that characterize them. This variation is characteristic of structural elements in Stadium II of deformations, when the beams do not have constant stiffness, resulting from the change in the stiffness of the materials that constitute them [32].

The groups of beams REF-1, D-1 and Q-1 presented the following results of the cracking moment $6.24 \mathrm{kN} \cdot \mathrm{m}, 8.3 \mathrm{kN} \cdot \mathrm{m}$ and $8.82 \mathrm{kN} \cdot \mathrm{m}$, respectively.

\subsection{Support load and self-weight ratio}

The ratio between the support load obtained experimentally and the proper weight estimated for each beam was carried out to determine the efficiency of the structures. The results of the efficiency factors found for all groups of beams tested (REF, D and Q) were respectively: $159.35 \pm 6.78 ; 285.67 \pm 7.31 ; 279.82 \pm 9.33$. 


\subsection{Rupture mode}

The rupture mode of the reference beams (REF) in relation to the samples of groups $\mathrm{D}$ and $\mathrm{Q}$ were different, however the behavior observed in the beams of groups D and Q were similar. All the structural elements that made up the REF group showed, at the beginning of the collapse state due to bending stresses, longitudinal reinforcement flow characterized by the opening of large cracks in the tensioned region, without breaking in the compressed concrete area due to the last deformations at compression. This behavior is characteristic of structural elements in domain 2 of deformations in the ELU, according to ABNT NBR 6118 [16]. Figure 10 shows the beams of the reference group (REF) after the mechanical tests performed.

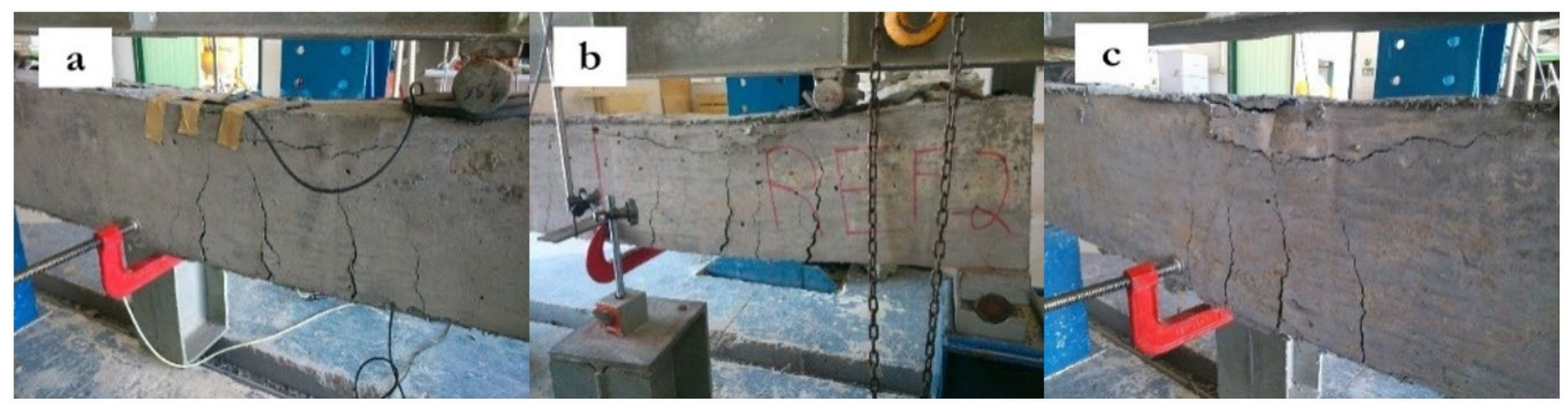

Figure 10. Beams of the reference group (REF) after four-point bending tests a) REF-1. b) REF-2. c) REF-3.

The $M_{n}$ calculated with the reinforcement was equal to $45.6 \mathrm{kN} \cdot \mathrm{m}$, this explains the change from rupture mode to shear.

Among the samples that made up group D, two of them (D-1 and D-3) did not show rupture until the maximum application loads established for the tests were reached. The beam D-2 presented a rupture close to the support, due to the shear in the GFRP profile at the bottom, which led to the subsequent rupture in the beam due to the shear efforts. Figure 11 shows the beams of group D after the four-point bending tests.
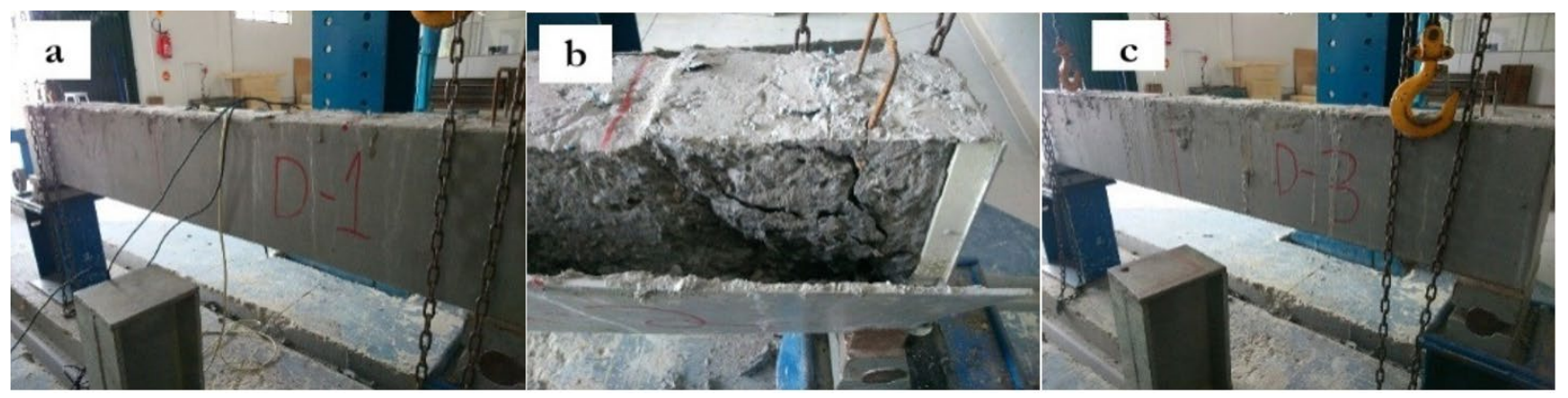

Figure 11. Beams of the group D after four-point bending tests. a) D-1. b) D-2. c) D-3.

The beams of group Q showed a similar behavior in relation to the elements of group D, and the sample Q-1 did not rupture until reaching the maximum load stipulated for the tests. The beams Q-2 and Q-3, on the other hand, showed rupture close to the supports due to the shear of the GFRP profile in the lower part, which subsequently caused the rupture in the beams in this region, due to the acting shear forces.

Beams D-2 and Q-3 showed unevenness in the supports, due to errors during their execution, and due to this, the rupture of the profiles in these elements occurred in the region where the beam was not fully supported, consequently reducing the contact area, that favored the collapse in these regions. 


\section{CONCLUSIONS}

After the tests performed, and through the results obtained, it appears that the GFRP profiles showed considerably increasing their mechanical strength, and their use as a partial substitute for transverse reinforcement proved to be effective.

The results show that there was no significant difference for the results of the samples of the groups that had the profiles of GFRP, therefore it is inferred that the spacing used for the transverse reinforcement in each group was not a relevant factor to justify the mechanical performance of the beams, but the presence of the profiles, and that the different spacing did not generate loss or gain of mechanical resistance in the analyzed samples.

Through the tests and the results obtained, the epoxy resin used to adhere the reinforced concrete structure to the GFRP profiles showed satisfactory performance.

The presence of GFRP profiles in the beams contributed to the increase of their stiffness, in relation to the structural reference elements (REF).

The strength gains obtained in the samples that had the GFRP profiles were the result of the joint action of the profiles and the tensioned longitudinal reinforcement.

The presence of GFRP profiles in the beams contributed to the increase in cracking moments, it can be deduced that such increase occurred due to the tensile stress resisted by these structures.

The theoretical results of cracking moments, last moments of resistance, and deformation domains predicted for the ultimate limit state in the reference beams showed a good correlation with the experimental results obtained.

The theoretical results of the reinforced beams, on the other hand, presented conservative predictions, with all tests on reinforced beams obtaining results superior to those calculated.

The graphical results of longitudinal deformation of the materials that make up the beams showed that the GFRP profiles worked together with the reinforced concrete structure, so the composite design structure showed satisfactory behavior.

The presence of GFRP profiles in the beams significantly increased the efficiency of the structures, when comparing the maximum loads obtained experimentally in relation to the estimated weight of the beams, and the presence of the GFRP profiles did not contribute significantly to the increase of the weight of the samples analyzed.

\section{REFERENCES}

[1] American Society for Testing and Materials. ASTM D3878 - 16: Standard Terminology for Composite Materials. United States: ASTM, 2016, 6 p.

[2] G. M. Santos, C. A. Gomes, and F. K. Arakaki, "Análise da propriedade mecânica de tração em perfis estruturais pultrudados em fibra de vidro e resina termofixa," in XIII INIC IX EPG, São José dos Campos, São Paulo, 2009, pp. 1-6. Accessed: Dec. 2016. [Online]. Available: www.inicepg.univap.br/cd/INIC_2009/anais/arquivos/0980_0572_01.pdf

[3] J. A. Gonilha et al., "Durability of GFRP-concrete adhesively bonded connections: Experimental and numerical studies," Eng. Struc., v. 168, p.784-798, maio 2018. http://dx.doi.org/10.1016/j.engstruct.2018.05.018.

[4] A. S. Mosallam "Composites in construction," in Handbook of Materials Selection, M. Kutz, et al., New York, NY, John Wiley \& Sons, Inc., 2002. ch. 45, pp. 1369-1420. Accssed: Set. de 2019. [Online]. Available: https://www.researchgate.net/publication/260834646.

[5] V. Mara, R. Haghani, and P. Harrysin, "Bridge decks of fibre reinforced polymer (FRP): a sustainable solution," Constr. Build. Mater., vol. 50, pp. 190-199, Jan. 2014. http://doi.org/10.1016/j.conbuildmat.2013.09.036.

[6] H. Xin et al., "Analytical and experimental evaluation of flexural behavior of FRP pultruded composite profiles for bridge deck structural design," Constr. Build. Mater., vol. 150, pp. 123-149, Set. 2017. http://dx.doi.org/10.1016/j.conbuildmat.2017.05.212.

[7] J. R. Correia, Utilização de Perfis Pultrudidos de Fibra de Vidro (GFRP) na Construção. Porto, Portugal: Fac. Eng., Univ. do Porto, 2006. 20 p.

[8] H. Fergani et al., "Durability and degradation mechanisms of GFRP reinforcement subjected to severe environments and sustained stress," Constr Build Mater, vol. 170, pp. 637-648, May 2018. http://dx.doi.org/10.1016/j.conbuildmat.2018.03.092.

[9] A. El-nemr et al., "Evaluation of the flexural strength and serviceability of concrete beams reinforced with different types of GFRP bars," Eng Struc, v. 173, pp. 606-619, Oct. 2018. http://dx.doi.org/10.1016/j.engstruct.2018.06.089.

[10] M. C. Pearson, T. Donchev, and M. Limbachiya, "An investigation into the sustainability of frp reinforcement bars," in CDCC-11 4th Intern. Conf. Durability Sustainability of Fibre Reinforced Polymer (FRP) Composites for Construction and Rehabilitation, Quebec City, Canada, Jul. 2011, pp. 71-80.

[11] M. Najm, "Investigating the use of fiber-reinforced polymer bars in concrete," Master thesis, Dept. Civ. Environ. Eng, Massachusetts Inst. Technol., Cambridge, MA, USA, 2012. [Online]. Available: https://dspace.mit.edu/handle/1721.1/74409. 
[12] J. R. Correia, F. A. Branco, and J. Ferreira, “GFRP-concrete hybridcross-sections for floorsofbuildings,” Eng Struc, vol. 31, no. 6, pp. 1331-1343, June 2009. http://dx.doi.org/10.1016/j.engstruct.2008.04.021.

[13] X. Sha, and J. S. Davidson, "Analysis of interfacial stresses in concrete beams strengthened by externally bonded FRP laminates using composite beam theory," Compos Struct, vol. 19, pp. 2020, 2020., http://dx.doi.org/10.1016/j.compstruct.2020.112235.

[14] A. Koaik, S. Bel, and B. Jurkiewiez, "Experimental tests and analytical model of concrete-GFRP hybrid beams under flexure," Compos Struct, vol. 180, pp. 192-210, Nov. 2017. https://doi.org/10.1016/j.compstruct.2017.07.059.

[15] A. A. Mohammed et al., "State-of-the-art of prefabricated FRP composite jackets for structural repair," Eng Sci Technol, vol. 19, pp. 2020, 2020., http://dx.doi.org/10.1016/j.jestch.2020.02.006.

[16] Associação Brasileira de Normas Técnicas. NBR 6118: Projeto de Estruturas de Concreto - Procedimento. Rio de Janeiro, RJ: ABNT, 2014. 236 p.

[17] R. C. Carvalho, and J. R. Filho, “Cálculo e detalhamento de estruturas usuais de concreto armado: segundo NBR 6118:2014,” 4. ed. São Carlos: Editora EdUFSCar, 2014.

[18] American Concrete Institute, ACI 440.2R-08: Guide for the Design and Construction of Externally Bonded FRP Systems for Strengthening Concrete Structures. Farmington Hills, MI, USA: ACI, 2008. 80 p

[19] American Concrete Institute, ACI 318-05: Buildingcoderequirements for Structural Concrete and Comentary. Farmington Hills, MI, USA: ACI, 2005, $1445 \mathrm{p}$.

[20] Y. H. Mugahed Amran et al., "RC beam strengthening using hinge and anchorage approach," Resul. Mater., vol. 5, no. 10047. Nov. 2020, p. 1-17. http://dx.doi.org/10.1016/j.rinma.2019.100047.

[21] A. Khalifa et al., "Contribution of externally bonded FRP to the Shear Capacity of RC Flexural Members," J Compos Constr, vol. 2 , no. 4, pp. 195-203. https://doi.org/10.1061/(ASCE)1090-0268(1998)2:4(195).

[22] J. G. Teng et al. "Recent research on intermediate crack induced debonding in FRP Strengthened Beams," in Proc. 4th Int. Conf. Adv. Comp. Mater. Brid. Struc., 2004, Calgary, AB, Canada.

[23] J. G. Teng et al., "Intermediate crack induced debonding in RC beams and slabs," Construction and Building Materials, vol. 17, no 67, pp. 447-462, Sept./Out. 2003. http://dx.doi.org/10.1016/S0950-0618(03)00043-6

[24] Associação Brasileira de Normas Técnicas, NBR 5738: Concreto - Procedimento para Moldagem e Cura de Corpos de Prova. Rio de Janeiro, RJ: ABNT, 2015, 9 p.

[25] American Society for Testing and Materials, ASTM C78/C78 - 16: Standard Test Method for Flexural Strength of Concrete. Using Simple Beam with Third-Point Loading. United States: ASTM, 2016. 4 p.

[26] Associação Brasileira de Normas Técnicas, NBR 5739: Concreto - Ensaio de compressão de corpos-de-prova cilíndricos. Rio de Janeiro, RJ: ABNT, 2007, 9 p.

[27] Associação Brasileira de Normas Técnicas, NBR 8522: Concreto - Determinação do módulo estático de elasticidade à compressão. Rio de Janeiro, RJ: ABNT, 2008, 16 p.

[28] Associação Brasileira de Normas Técnicas, NBR NM 67: Concreto - Determinação da consistência pelo abatimento do tronco de cone. Rio de Janeiro, RJ: ABNT, 1996, 8 p.

[29] Associação Brasileira de Normas Técnicas, NBR NM 248: Agregados - Determinação da composição granulométrica. Rio de Janeiro, RJ: ABNT, 2003, 6 p.

[30] I. C. Canalli "Estudo de comportamento de estrutura mista de concreto e perfil pultrudado de PRFV sob flexão," M.S. thesis, Civil Eng. Grad. Prog., Univ. Fed. de Santa Catarina, Florianópolis, 2010. [Online]. Available: https://repositorio.ufsc.br/handle/123456789/94068.

[31] A. D. Figueiredo, J. Tanesi, and A. A. Nince, “Concreto com fibras de polipropileno (CFP)," Téchne, vol. 10, no. 66, pp. 48-51, 2002.

[32] F. Leonhardt, Construções de concreto Vol. 4: Verificação da Capacidade de Utilização: Limitação da Fissura, Deformações, Redistribuição de Momentos e Teorias das Linhas de Ruptura em Estruturas de Concreto Armado, 1. Ed. Rio de Janeiro, RJ: Interciência, 1979. $210 \mathrm{p}$.

Author contributions: ISH: proposed the research, performed the literature review, the experimental campaign and wrote this article; JHP: handled and review data and writing; AW: performed the literature review, implemented the GFRP reinforcement theoretical calculus, wrote this article and handled its review; EGPA: proposed the research, supervised the student ISH, proposed the experimental campaign, wrote this article and handled its review.

Editors: José Marcio Calixto, José Luiz Antunes de Oliveira e Sousa, Guilherme Aris Parsekian. 